single pairs of measurements in 200 patients. We therefore propose that, with the reservations we have expressed elsewhere, ${ }^{7}$ our adjustment (adjusted calcium $=$ calcium -0.025 albumin $+1.0 \mathrm{mmol} / \mathrm{l}$ ) remains a valuable screening procedure for deciding which of the many patients with abnormal albumin concentrations need further investigation of calcium homoeostasis. Until better data become available the average regression coefficient of $0.025 \mathrm{mmol}$ calcium $/ \mathrm{g}$ albumin should be retained.

R B PAYNe

A J LitTle

R B WILliams JOHN R MILNER

Department of Chemical Pathology,

St James's University Hospital, 1 Payne, R B, et al, British Medical fournal, 1973 , Robertson, W G, Clinica Chimica Acta, 1969, 24.
149.

Pedersen, K O, Scandinavian fournal of Clinical and Laboratory Investigation, 1970, 25, 223.

4 Rose, G A, Clinica Chimica Acta, 1972, 37.343 and Laboratory Investigation 1972 30, Clin Berry, E M, et al, British Medical fournal, 1973

Payne, R B, Lancet, 1973, 2, 375

SIR,-Any reader of this journal, unaware of the current position regarding the measurement of albumin in serum, would assume from the communication of $\mathrm{Dr} R \mathrm{~W}$ Pain and others (13 December, p 617), in which the "corrected" calcium concept was challenged, that the bromocresol green (BCG) method is specific for albumin. This is not the case.

A recent communication ${ }^{1}$ has shown that BCG is not specific for albumin and reacts with other proteins, mainly $\alpha$ - and $\beta$-globulins in the serum. The disagreemen between the BCG method and the specific methods involving immunoprecipitation is greatest at low albumin levels, -4 the BCG method considerably overestimating the albumin level in most cases. This is not surprising since most hypoalbuminaemic sera show increases in the $\alpha$-globulin fractions and the BCG overestimation of the albumin is related to the degree of these increases. This overestimation can be as much as $300 \%$ at very low albumin levels, although the average overestimation at a true albumin level of $20 \mathrm{~g} / 1$ is about $30 \%$ It is only with normal sera that the BCG methods give albumin results in good agreement with immunoprecipitation techniques since high albumin levels tend to be underestimated by them. It has also been claimed that bilirubin in serum interferes with the binding of BCG with albumin. ${ }^{4}$

Since BCG reacts with a number of serum proteins, and this is the case in normal as well as abnormal sera, it is not surprising to find that there is not a constant relationship between calcium and "BCG-reactive material" in multiple analyses in the same individua during a hospital stay. It would be surprising if there was. In the postural and tourniquet experiments carried out by $D$ Pain and his colleagues one might expec closer agreement between the regression coefficients, but since we do not know whether all the BCG-reactive proteins mimic albumin in these situations it would be unwise to assume that they do.

Whether or not a correction can be applied to calcium levels to compensate for abnormal albumin levels will be determined only when the most accurate methods available are used by laboratories, and the practice of using non-specific methods which are convenient for automated machines will serve only to perpetuate the confusion and uncertainty. The BCG method for albumin should be used as a screening method only, and where accurate levels of albumin in abnormal sera are required a proved electrophoresis or immunoprecipitation technique should be used.

Biochemistry Department,

Worcester
Worcester

DAVID WEBSTER

1 Webster, D, Clinica Chimica Acta, 1974, 53, 109. D, Clinica Chimica Acra, 1974, 53, 109. 53, 101.
Slater. Le al, Annals of Clinical Biochemistry, 1975, 12, 33. Acta, 1974, 55, 259 .

\section{Changing status of doctors in Finland}

SIR,-I feel it necessary, for the information of your international readership, to comment briefly on the letter from Dr J Eskola and others (13 December, $p$ 651) criticising my article on this subject ( 1 November, p 273).

Regrettably, the letter was written in a somewhat brusque and aggressive tone. It is always natural, of course, that matters like this are seen, and also should be seen, from different sides. In this particular case it is quite natural that there may be some differences of opinion because the writers of the letter represent the highest administrative level while I personally represent rnerely the bottom level. (Mr Ruoppila is the chief of the administrative office at the National Board of Health, Dr Miettinen is the chief of the bureau of mental health, and Dr Eskola is a medical officer in the same bureau.) In listing what they regard as "obvious faults" in my article they seem to agree with me in most cases and are only using slightly different wording.

Firstly, contracts for jobs. Here we seem to agree that the principal jobs are tied to fixed periods, which is a change Secondly, the treasurer. This depends on how we wish to understand this concept. Before the passage of the Act we can say that the doctor may have been acting as a treasurer collecting part of his income from the patients. In that sense it can perhaps be said that there were "private treasurers." The former local hospitals also had treasurers, which in many cases were parttime appointments in addition to the person's ordinary job. The position of treasurer in health centres as described in my article has existed only since the passage of the Act, since before then we did not even have the health centres. Thirdly, the new method of payment was indeed the result of collective bargaining as is usually the case. I referred to the communal salary agreement and described the new changed system. The comment of Dr Eskola and his colleagues can be seen as a welcome clarification of the matter, in which they otherwise seem to agree.

Fourthly, the system of medical education that I described was right at the time the article was written. It was right also at the time I corrected the proof. This shortened system had been a matter of inner political dispute for many years and had come under criticism from different sides. The change that happened after my returning the corrected article was really rapid and could not have been foreseen. Dr Eskola and his colleagues have therefore performed a useful service in describin the latest system. Fifthly, as the writers should know, the position of chief medical officer in a hospital is already for a fixed period. In the proposed Bill there is the suggestion that the chie medical administrator of the region also should be appointed for a fixed period.

Thus Dr Eskola and his colleagues seem to agree with me in most cases, using only slightly different terms. The whole letter perhaps reflects too legalistic an interpretation of words. With limited space at one's disposal it is very difficult to write an article which would include everything. In this matter that would mean writing a book. The $B M F$ might have had some objection to that.

Lapua, Finland

PERTTI KeKKI

\section{Prophylactic treatment of postgonococcal} urethritis

SIR,-Postgonococcal urethritis is the most troublesome feature met with now in the management of gonorrhoea in the male. As your expert points out (1 November, p 267), the aetiology is obscure but is considered generally to be of an infectious nature. The incidence is related to the type of treatment prescribed for the gonococcal infection. After penicillin therapy as many as $20 \%{ }^{1}$ to $30 \%{ }_{\circ}^{2}$ of patients may develop postgonococcal urethritis, while with tetracycline the incidence is around $6 \% \cdot \cdot^{3}$ In other respects tetracycline is inferior to penicillin in the treatment of gonorrhoea, and when it was decided to try to reduce the incidence of postgonococcal urethritis in this clinic it seemed reasonable to adopt a regimen in which penicillin was prescribed for the gonococcal infection and a wide-spectrum antibiotic as prophylactic treatment for postgonococcal urethritis. The results so far of this combined therapy are so promising as to be worth recording.

The treatment regimen consisted of one injection of procaine penicillin $1.8 \mathrm{MU}$ followed in two or at the most three days by Deteclo $300 \mathrm{mg}$ three times a day for three days. Deteclo was chosen as this combination of tetracyclines had been thoroughly tested in extensive clinical trials and had proved to be as effective in nongonococcal urethritis as any of the other tetracyclines and singularly free from side effects. Deteclo was not prescribed if there was any microscopical evidence to suggest that the gonococcal infection persisted. Nor was this antibiotic prescribed if the interval between penicillin treatment and the first follow-up examination was longer than four days or if the initial treatment was other than penicillin.

In 1972, the year before this combined treatment was brought into use, 1654 patients received the standard treatment of procaine penicillin $1.8 \mathrm{MU}$ and $150\left(9 \cdot 1^{\circ}\right)$ developed postgonococcal urethritis. Combined penicillin/Deteclo treatment was given to 1397 patients in 1973 and to 1605 in 1974 . The incidence of postgonococcal urethritis with this treatment was $2.9 \%$ (40 cases) in 1973 and $3.2 \%$ (51) in 1974.

That this reduction in incidence was not due to any natural phenomenon but was related to the treatment is suggested by the fact that postgonococcal urethritis developed in 13 patients $(11.9 \%)$ out of 109 treated with penicillin alone in 1973 and in 15 $(11.8 \%)$ out of 127 treated similarly in 1974 and also by the unchanging incidence of postgonococcal urethritis in patients treated initially with antibiotics other than penicillin. Mainly these were cephaloridine, cephalexin in a single dose, kanamycin, and spectinomycin. Such treatments were given to 170 patients in 1972, 380 in 1973, and 182 in 
1974. The incidence of postgonococcal us with various corticosteroid creams and urethritis in these years was $11.7 \%$ (20 ointments the healing rate varied between cases), $12 \cdot 6 \%(48)$, and $12 \cdot 1 \%$ (22) respectively.

VD Department,

General Hospital

Birmingham

1 Wilcox, R R, British fournal of Venereal Diseases, $1970,46,412$

Gray, R C F, Phillips, I, and Nicol, C S, British fournal of Venereal Diseases, 1970, 46, 401.

Diseases, 1970, 46, 398.

\section{Teething myths}

SIR,-I read your leading article "Teething myths" (13 December, p 604) and, while in no way questioning the time-honoured historical aspects of the subject, as a dentist I know that the teeth of an infant can and do cause local disturbances when erupting into the oral cavity. The results of a longitudinal study which I undertook recording 4480 episodes of tooth eruption in 224 children has helped to demonstrate this quite clearly.

In a leading article in April 1970 you gave guidance on treatment. ${ }^{2}$ Now, however, five years later treatment of the symptoms of this common problem has been omitted, presumably because teething has once again assumed the mantle of being a myth.

Margaret SEWARD British Postgraduate Medical Federation, London WCI

\footnotetext{
1 Seward, M H, British Dental fournal, 1971, 130, 2 British Medical fournal, 1970, 2, 67.
}

** We did not suggest that the local disturbances that are undoubtedly associated with the eruption of the primary teeth are in any way mythical. The myth to which we wished to draw attention was the dangerous one that may lead to the symptoms of serious systemic disease being dismissed as due to "teething."-ED, BMF.

\section{Steroids and common skin diseases}

SIR,-Drs P W M Copeman and S Selwyn (1 November, p 264) state that the indiscriminate use of corticosteroids in common skin diseases is dangerous. As a substitute, particularly in the treatment of stasis ulcers and varicose eczema, they advocate the use of Miol lotion and cream, with which they claim encouraging results.

Some doubts, however, must be raised about the method of their investigation. The authors state that "in the case of leg ulcers, however, limb elevation and bandaging or supportive hosiery were continued." It is not clear if these patients were treated in hospital or as outpatients. If they were admitted and treated with bed rest and limb elevation no conclusions may be drawn from the fact that the ulcers healed, since simple varicose ulcers will do so with bed rest even if nothing else is done. As no control series is reported nothing can be learnt from a possible difference in the rate of healing.

It is also remarkable that in this series "in all cases prolonged conventional treatment with corticosteroids-often with antibiotics-was unsuccessful." Since in several series of cases of varicose eczema treated by
80 and $100 \%$ one might suspect that these patients had not been adequately treated before admission to Westminster Hospital. They could, for example, have been treated without effective compression bandages. It should be remembered that in the treatment of both varicose stasis ulcers and varicose eczema the physical treatment by compression and not the topical application of some cream or other is the most important. However, particularly in cases of severe itching, application of a corticosteroid cream is valuable and reduces healing time. Furthermore, with the exception of fluocinolone and fluclorolone, we have not seen any side effects in treating varicose eczema even with potent corticosteroids.

Slottsstaden Clinic,

Malmö, Sweden

\section{Diagnosis of pericardial effusion by} echocardiography

SIR,-Dr P Kramer and his colleagues (6 December, p 564), diagnosed pericardial effusion and tamponade in their patients on clinical and chest radiographic criteria alone. In patients with renal failure the cardiac dilatation and failure secondary to prolonged and often poorly controlled hypertension may cause this evidence to be misleading.

A more reliable diagnosis may be reached by either radioisotopic ${ }^{l}$ or ultrasound techniques. The latter is the more sensitive ${ }^{2}$ and may detect effusions as small as $20 \mathrm{ml}$ Approximate measurement of the effusion is possible by echocardiography, and pericardial tamponade may be diagnosed if there is posterior motion of the interventricular septum with decreased left ventricular dimension on inspiration. ${ }^{3}$

Pericardiocentesis, even with electrocardiographic and radiographic control, is not without hazard." We feel that it should be performed without prior echocardiography or isotope scanning only in acute lifethreatening situations. In less severely ill patients the presence of an effusion should be confirmed by these techniques and the fluid then aspirated if there is failure to respond to conservative therapy.

\section{G C MACARTHUR}

Department of Medicine,
Hammersmith Hospital,

A J REES

Lomdon $\mathbb{W} 12$

1 Weiss, E R, et al, American fournal of Cardiology, Horowitz, M S, et al, Circulation, 1974, 50, 239.

Daruz, $\mathbf{R}$, and Martin $\mathbf{R}$ H, Annals of Internal Medicine, 1972, 77, 592 .

\section{Gastric ulcer-short-term healing and} long-term response

SIR,-Your leading anticle on this subject (12 July, p 61) summarised well this complex problem. However, we wish to comment on several points which have been clarified in a study carried out in Australia and published since your article appeared.1 Factors studied ing rate, sex of patient, and smoking status. None of these were found to affect recurrence rate. Recurrence was more frequent relevant to your discussion were initial heal- with larger ulcers: $53.6 \%$ of ulcers greater than $51 \mathrm{~mm}^{2}$ in area compared with $25 \%$ of ulcers less than $51 \mathrm{~mm}^{2}$ recurred, regardless of whether the patient had been discharged from hospital with the ulcer healed or unhealed $(P=0.005)$. On the other hand the rate of initial healing in hospital did not influence the ultimate recurrence ratethose patients whose ulcers healed rapidly during the period of initial hospital treatment did not necessarily have a longer remission. Complete initial healing with medical triatment produced a better longterm response than incomplete healing, as shown by others. ${ }^{2}$ In view of this, and of the morbidity of ulcer disease demonstrated by Watkinson, ${ }^{3}$ a plea is made for all doctors to insist on a period of treatment, preferably in hospital, and to achieve complete healing in all patients with chronic gastric ulcer. Our current practice is to recommend surgery if the ulcer recurs within a period of two years following initial healing or if other complications occur. ${ }^{4}$ Using these criteria $77 \%$ of patients in a placebo-treated group came to surgery. ${ }^{5}$ Hence it is seen that Australian findings support your conclusions regarding operation.

D W PIPER M J GREIG

\section{K D LANDECKER}

Departments of Medicine and Gastroenterology, Royal North Shore Hospital,

Australia

1 Piper, D W, et al, Gut, 1975, 16, 714.

2 Sun, D C H, and Stempien, S J, Gastroenterology, 1971, 61, 576.

4 Piper, D W, Cumberland, V H, and Fevre, D I, Drugs, $1975,10.56$.
10. Gastroenterology, 1972, 63, 399 .

\section{Cooking the Christmas turkey}

SIR,-I read with interest Dr Norman D Noah's (20 December, p 714) comprehensive list of instructions and warnings on the preparation and cooking of the Christmas bird. Having reviewed the information given with supermarket turkeys, presented in four well-known cookery books, ${ }^{1-4}$ collected from the catering departments of the three general hospitals in Leicester, recalled from my bachelor cooking days, and supplied, last but not least, by my wife, I must disappoint him in that to judge from this small sample it is by no means "usual to allow . . $204^{\circ} \mathrm{C}$ $\left(400^{\circ} \mathrm{F}\right.$-regulo 6)" for roasting. Recommended oven temperatures range from 325 to $375^{\circ} \mathrm{F}$ (163 to $190^{\circ} \mathrm{C}$ ) for a fairly constant allowance of 15-20 minutes per lb (35-45 min per $\mathrm{kg}$ ) plus u.p to one-half hour at the end. All the above sources also suggest stuffing the bird before cooking. I wonder if these facts and those mentioned in $\mathrm{Dr}$ Noah's article are the cause of so much postChristmas gastrointestinal upset rather than the assault by mere quantity of substances and aloohol consumed that is often blamed. Food for thought?

D L CARR-LOCKE

Department of Medicine

University of Leicester

1 The Robert Carrier Cookbook. London, Sphere Books, 1970.
2 Mrs Beaton's All About Cookery. London, Ward Mrs Beaton's All About Cookery. London, Ward
Lock, 1970.

The Constance Spry Cookery Book. London, Pan
Books, 1972. The Penguin Cooker
Penguin Books, 1971. 